\title{
Reflections on 65 Years of the APSA Congressional Fellowship Program
}

Bruce Oppenheimer, Vanderbilt University

Guest Editor: Frances E. Lee, University of Maryland

\section{I} $\mathrm{t}$ is hard to believe that it's been 43 years since I was an APSA congressional fellow. Not only do the memories of that year remain vivid, but the benefits of that experience still accrue to my professional life as sonal life through friends that I made during that year.

Reading the seven essays from recent program participants reminded me of the diversity of experiences that congressional fellows have and the lessons that they take away. The year on the Hill informs teaching about Congress, as is evident in the Ringenberg essay. It raises questions about the existing scholarly literature and challenges major findings on the difficulties in measuring legislative effectiveness in the Senate, as in the Johnston analysis. It leads to questioning whether members' public policy and reelection goals are mutually exclusive or intertwined, as explored in the Hager piece. It provides a feel for the intricacies of process, as Owens observes in the role of a Senate chair in the obstruction of a Supreme Court nomination. It allows for a front-row seat to observe the rules and norms of Congress-and sometimes, bucking those norms-as described in the Alexander piece. It nuances the understanding of how important legislative work continues even in an era when gridlock seems to be the norm, as Brown analyzes in overseeing the Telecommunications Act of 1996 and Howard documents in the Senate Armed Services Committee producing must-pass legislation.

But as congressional fellows of earlier generations, myself included, can attest, these are just the first returns from investing a year on Capitol Hill. Although the work that participants in the program do as part of the congressional office staff significantly constrains the time available for research, each new class of political scientists beginning the program should see it as an investment. Like the apple tree one plants in the backyard, it may require a lot of tending initially, but then it keeps bearing fruit year after year and produces bumper crops often when one least expects. The APSA Congressional Fellowship Program (CFP) is an investment that produces modest short-term yields and bountiful long-term payoffs.

In reading the essays of these recent CFPers, I was reminded that Cathy Rudder, Larry Dodd, and I engaged in a similar undertaking following our congressional fellowship year, 1974-75. Sheilah Mann-Sheilah Koeppen at the time-invited the three of us to write pieces applying what we learned during our year to teaching about the House of Representatives in the DEA News, an APSA publication that dealt with educational issues and for which she was executive editor. The 1974-75 congressional fellowship year had coincided with the first session of the 94th Congress in which the huge Watergate class of 75 first-term Democrats mobilized in the implementation of a broad range of reforms. ${ }^{1}$ The Congress we observed was considerably different than the conceptual Congress that we and others were teaching at our respective institutions. The Era of Committee Government was at an end. Committee chairs had lost power and faced caucus elections beginning at the start of the 93rd Congress to retain their positions. The House Democratic Caucus replaced three incumbent House chairs in organizing for the 94th Congress. Seniority no longer provided for automatic retention. Power was dispersed in two directions: to subcommittees and to parties and party leaders. The conservative coalition was on the wane. A new budget process was being tested for the first time. Although it was uncertain whether all of these and other changes would persist-some of them proved to be transitional-we knew that the return to committee government, even in a modified form, was not an option.

For the DEA News essays, Larry covered the emergence of party government (Dodd 1976), Cathy dealt with the new budget process and the changes in finance policy (Rudder 1976), and I handled subcommittee government and congressional reform (Oppenheimer 1976). Each of us had had a bird'seye view during our fellowship year. Larry spent half his year in the House Majority Whip Office and witnessed the first steps in the reinvigoration of a party organization and leadership. 
Cathy joined the staff of Abner Mikva (D-IL), a Chicago reformer and a member of the House Ways and Means Committee, for a segment of her fellowship experience. And although it was then common practice to split the year between two different office assignments, I wound up staying the entire year with Gillis Long (D-LA), a moderate southerner from a largely rural district, whose position on the Rules Committee allowed me to observe not only changes that were making the committee an arm of the party leadership, but also the increased role of subcommittees and subcommittee chairs in the management of legislation (in addition to getting schooled in and entertained with Louisiana politics and food). ${ }^{2}$

Those of us in classes of APSA congressional fellows during that time witnessed changes in Congress of a magnitude not experienced since the revolt against Speaker Joseph Cannon in 1910. That revolt signaled the beginning of the Era of Committee Government. Understanding what was replacing committee government was a major challenge for congressional scholars. It would take us a few years to fully appreciate that Congress and other political institutions evolve constantly in response to contextual change-even the Era of Committee Government was far from constant. Subsequent classes of congressional fellows would join us and others in assuming responsibility for monitoring and analyzing the ongoing changes: from the consolidation of power within the Democratic party during the O'Neill and Wright speakerships, to the Republican Revolution of the Gingrich years, to the struggles over gridlock with polarized parties and narrow majorities of the past two decades. 3 Throughout, the key has been that political scientists in the CFP, possessing the appropriate knowledge, training, and access, have been able to analyze the changes in broader historical context and to provide a systematic understanding of the institution. participants in the program, have generously contributed over the years to ensure that new generations of students have exposure to current research on the most powerful national legislature.

The most visible effects of the fellowship year for me are in the research projects and publications that have resulted either directly or indirectly from my participation in the program. Work on the Rules Committee, the filibuster, the 1976 House majority leader contest, and a range of pieces on energy policy all had their impetus from that experience. The stimulation for many of these projects originated during my fellowship year. Observing the Rules Committee and working with a member who was close to the party leadership not only enabled me to see how the role of the Committee had changed drastically, but also gave me a more nuanced understanding of how it became an effective arm of the majority party leadership in managing the House. It was through Gillis Long's management of Richard Bolling's campaign for majority leader in the exceptionally close 1976 contest that I gained access to and insights about a leadership contest that was probably unprecedented. Many of my professional colleagues and media sources viewed the campaign largely in ideological terms, not understanding that many other dimensions were in play in members choosing whom to support.4 In the end a deal involving New York Mayor Abe Beame and Chicago Mayor Richard Daley that delivered almost all the House members from those two cities and New Jersey to Jim Wright in exchange for some public works commitments proved crucial. 5

One of the payoffs from the program is that congressional fellows establish relationships with a range of people who may subsequently assist in their research endeavors. In some cases, those individuals may open doors or provide access for interviews, not to mention career advancement. For example,

\section{Those of us in classes of APSA congressional fellows during that time witnessed changes in Congress of a magnitude not experienced since the revolt against Speaker Joseph Cannon in 1910. That revolt signaled the beginning of the Era of Committee Government.}

By the end of our Congressional Fellowship year, Larry Dodd and I, who first met during our fellowship year, realized how many congressional scholars-both our contemporaries in the program and other more mature scholars who continued to do "soaking and poking" on Capitol Hill-were engaged in research projects dealing with some aspects of the changes and reforms that were ongoing in the early to mid1970s. We decided to pull together their work in a collection that would be stimulating to scholars of Congress and their graduate students but would also be accessible to undergraduates. That effort resulted in Congress Reconsidered (Dodd and Oppenheimer 1977). We had no idea that the book initially published by Praeger would lead at this point to ten subsequent editions with CQ Press. Indeed, Congress and political institutions in general are constantly changing, and congressional scholars, including many former the staffer that one interacts with as a congressional fellow may later win elective office. Sometimes help comes in most unexpected ways. I recall interviewing Congressman Lud Ashley (D-OH), who was at the time chair of the Ad Hoc Select Committee on Energy. He was running behind and his committee was meeting in the Capitol so my scheduled interview in his office turned into a "walk and talk." There was no time to establish rapport with him and his responses to my questions were terse. As we strode through the Capitol, Congressman Joe Moakley (D-MA) was coming the other way. Moakley was a member of the Rules Committee, and I had interviewed him when I'd been a fellow. There was no reason for him to remember me. As he approached, however, Moakley greeted us: "Hello, Lud. Hello, Bruce." Then turning to Ashley, he continued, "You know he did a really good job on the Rules Committee." My jaw dropped. 
Moakley had given me the stamp of approval, and Ashley's demeanor toward me and general responsiveness immediately shifted. ${ }^{6}$ Of course, the assist one gets to obtain an interview may contaminate the interview. That's one of the risks that congressional fellows take as participant observers or in elite interviews, either during the fellowship year or subsequently. When the alternatives are not getting an interview at all or having someone assist you in gaining access, the decision is an easy one.
These recent APSA congressional fellowship participants have now benefitted both from their graduate school training (in positive and normative theory, data collection, statistics, and American political institutions and behavior courses) and from their experiences during a year on the Hill at becoming skilled observers and interviewers. They now have a more complete repertoire available to attack the research questions that engage them over their fruitful scholarly careers.

\section{We are better at talking, interjecting, correcting, and in general demonstrating how smart we are than we are at being unobtrusive, observing and listening until an appropriate moment, being forgotten as the players interact, and allowing an interview weave itself into a conversation.}

Not only does the CFP assist with obtaining access, it allows participants to sharpen their skills as participant observers and interviewers. I suspect that neither of these roles comes naturally for academics. We are better at talking, interjecting, correcting, and in general demonstrating how smart we are than we are at being unobtrusive, observing and listening until an appropriate moment, being forgotten as the players interact, and allowing an interview weave itself into a conversation. "Soaking and poking" is a self-effacing, and perhaps even a demeaning, term for the method that those of us who have done participant observation and elite interviewing employed. It takes practice, skill, patience, and an ability to tolerate frustration, among other things. The CFP gives young congressional scholars an opportunity to acquire these talents.

If there is anything that has disappointed me about the study of legislative politics over the course of my career, it has been the decline that I have observed in the amount of published scholarship that employs participant observation and elite interviewing as part of the research methodologies. It is not infrequent that I review an article or book manuscript or read one in published form and think how much better the publication would have been if the authors had done some elite interviewing or observation. Sometimes scholars posit something about members' behavior that one cannot imagine them doing. In other instances, I wonder how much more interesting the manuscript would be if the researcher had gotten the reaction of members to their data and findings. Oftentimes, I suspect it would lead the authors to nuance their analyses or to add richness to the interpretations. More rarely, the researchers may even discover things during observation or interviews that they had never considered.

Yes, politicians can mislead or deceive even the most skilled scholarly observer or interviewer. That's why we employ data collection and analysis and do not rely on "soak and poke" approaches alone. But posited theory, hypothesis testing, and data analysis can also lead to incorrect or naïve interpretations.

\section{NOTES}

1. Although most of the changes occurred in the House, the Senate was not immune. Notably the cloture rule changed from two-thirds present and voting to three-fifths of the chamber.

2. One of my assignments while on Long's staff was to develop a rationale to extend Louisiana's open primary law which was already in place for state legislative elections to congressional elections in the state. Long was able to persuade the state Democratic party chair and Governor Edwin Edwards to support the change. In the short-term it assisted Democrats because many of them would win reelection prior to the general election and avoid being linked to the party's presidential nominee. It also meant that Republicans, often unopposed for their party's nomination, could not get a free ride to the general election while Democrats expended resources in contested primaries. In the longer-term, it undoubtedly fostered the growth of the Republican party in the state.

3. I have refrained from listing the many individuals and their publications that have contributed to our knowledge of Congress and how it has changed over the past five decades for two reasons. First, I am unintentionally bound to omit some individual or some important contribution. And second, the list would be so long that the reference section of this essay would be far longer than the essay itself.

4. In turn, my small role in that campaign led to a longer term relationship with Bolling in which he was willing to share perspectives on workings of Congress that were far from obvious. For example, he argued that logrolls were rarely about trades over votes on policy issues and far more often occurred in trading time priorities-two members, often gatekeepers, trading what each was eventually going to do but doing it sooner (or later).

5. James Howard (D-NJ) became chair of the Committee on Public Works when Wright vacated that position to become majority leader.

6. This episode fits perfectly with Dick Fenno's vignette about Moakley at the start of his book Congressional Travels (2007). In an instant Moakley not only realized who I was and why I was talking to Ashley, but he also decided to do something that he knew would help me and achieved it in under five seconds. I was not about to tell him that he had just contaminated my interview!

\section{REFERENCES}

Dodd, Lawrence C. 1976. "Emergence of Party Government in the House of Representatives." DEA News Supplement. Washington, DC: American Political Science Association, 1-5.

Dodd, Lawrence C., and Bruce I. Oppenheimer, eds. 1977. Congress Reconsidered. New York: Praeger.

Fenno, Richard F., Jr. 2007. Congressional Travels: Places, Connections, and Authenticity. New York: Pearson, Longman.

Oppenheimer, Bruce I. 1976. "Subcommittee Government and Congressional Reform: Perspectives for Studying the House of Representative." DEA News Supplement. Washington, DC: American Political Science Association, 8-11.

Rudder, Catherine. 1976. "The Budgetary Process and Finance Policy." DEA News Supplement. Washington, DC: American Political Science Association, 5-8. 


\section{SYMPOSIUM CONTRIBUTORS}

Brian Alexander is assistant professor of politics and government at Washington and Lee University and the incoming director of the WEL Washington Term Program. He served as an APSA congressional fellow in the US Senate in the 114th Congress. In 2015, Brian received a Steiger Fellowship for the development of a social theory of Congress. His current research examines legislative norms through field research and longitudinal data analysis. Brian may be reached at alexanderb@wlu.edu.

Justin S. Brown is assistant professor in the Zimmerman School of Advertising \& Mass Communications at the University of South Florida, teaching courses in telecommunications, law, ethics and qualitative research methods. His research focuses on telecommunications law and policy issues involving broadband deployment and new media. Justin served as the 2015-2016 MCI Communications Congressional Fellow, working on Capitol Hill in the office of Sen. Brian Schatz (D-HI) to help support his role as ranking minority member of the Communications, Technology, Innovation and the Internet subcommittee. He may be reached at justinsbrown@usf.edu

Lisa Hager is assistant professor of political science in the Department of History, Political Science, Philosophy, and Religion at South Dakota State University. She is also the adviser for the Legal Studies minor and Pre-Law Society. She was a 2015-2016 APSA congressional fellow in the office of Representative Daniel Lipinski (IL-3). Her research and teaching interests focus on American political institutions, particularly judicial and congressional politics and behavior. Lisa may be reached at lisa. hager@sdstate.edu.

Nicholas O. Howard is assistant professor in the Department of Political Science and Public
Administration at Auburn University at Montgomery, Alabama. His research, published in Legislative Studies Quarterly, focuses on how Congressional parliamentary rules and norms affect legislation. During 2015-2016 Nicholas served as an APSA congressional fellow in the office of Senator Orrin Hatch of Utah. Nicholas may be reached at nicholas.howard@aum.edu.

Travis Johnston is assistant professor of political science at University of Massachusetts, Boston. He served as a 2015-2016 APSA congressional fellow for the Senate Health, Education, Labor and Pensions Committee. He studies legislative institutions, electoral politics, and policymaking. He may be reached at travis.johnston@umb.edu.

Frances E. Lee is professor of Government and Politics at the University of Maryland and the guest editor of this symposium. She is coeditor of Legislative Studies Quarterly. She is author of Insecure Majorities: Congress and the Perpetual Campaign (University of Chicago Press, 2016), Beyond Ideology: Politics, Principles, and Partisanship in the US Senate (University of Chicago Press, 2009) and coauthor of Sizing Up The Senate: The Unequal Consequences of Equal Representation (University of Chicago Press, 1999). She is also coauthor of Congress and Its Members, currently in its 16th edition (Sage / CQ Press, 2018). Her research has appeared in numerous journal outlets, including the American Political Science Review, American Journal of Political Science, Journal of Politics, and others. She was an APSA congressional fellow in 2002-03. She may be reached at FLee1@umd.edu.

Bruce Oppenheimer is professor of political science at Vanderbilt University. His research primarily focuses on Congress and American political institutions. His primary current interest examines how process changes have affected the ability of
Congress to develop energy policy over the past half century. He is coeditor (with Lawrence Dodd) of Congress Reconsidered, the 11th edition of which was published by CQ Press in 2017. Oppenheimer's book, Sizing Up the Senate: The Unequal Consequences of Equal Representation, coauthored with Frances Lee, won the D.B. Hardeman Prize for the best book on Congress. He has been both an APSA congressional fellow and a Brookings Institution fellow and guest scholar.He may be reached at bruce.oppenheimer@ vanderbilt.edu.

Mark E. Owens is assistant professor of political science at the University of Texas at Tyler. During the APSA Congressional Fellowship Program for 2015-2016 he spent the year working for Senator Orrin Hatch (R-UT), President Pro-Tempore of the United States Senate.Mark may be reached at mowens@uttyler.edu.

Thomas Ringenberg is assistant professor of political science at Rockhurst University in Kansas City. He served as an APSA congressional fellow in the office of Rep. Wm. Lacy Clay, Jr. (MO-1; St. Louis). His research focuses on legislative studies and pedagogy issues. He serves as a member of the APSA Education Section's executive board. Tom can be reached at Thomas.Ringenberg@rockhurst.edu.

Daniel Stid is director of the Madison Initiative at the William and Flora Hewlett Foundation. He oversees the foundation's three-year, \$5 million effort to improve deliberation, negotiation, and compromise in Congress. He began his career teaching political science at Wabash College and is the author of The President as Statesman: Woodrow Wilson and the Constitution (University Press of Kansas, 1998). Daniel was also selected to be an APSA congressional fellow and served on the staff of Majority Leader Dick Armey in the US House of Representatives. He may be reached atdstid@hewlett.org. 